\title{
HORMONAL AND IMMUNOLOGICAL CHANGES DURING PREGNANCY PERIOD OF COWS
}

\author{
El-Masry KA ${ }^{1}$, El-Fouly HA ${ }^{1}$, Gabr SA*2 \\ ${ }^{1}$ Biological Applications Department, Radioisotope Applications Division, Nuclear Research Center, Atomic Energy Authority, Cairo, Egypt \\ ${ }^{2}$ Taif University, Khurma University Collage, Kingdom Saudi Arabia
}

Received - February 05, 2019; Revision - April 04, 2019; Accepted - May 26, 2019

Available Online - June 10, 2019

DOI: http://dx.doi.org/10.18006/2019.7(3).329.334

KEYWORDS
Cow
Pregnancy
E2-17 $\beta$
Testosterone
IgG

\begin{abstract}
The objective of present study was to determine the pattern and impact of pregnancy stage on the concentrations in serum estradiol-17 $\beta$ (E2-17 $\beta$ ), testosterone hormones and immunoglobulin G (IgG). For this purpose, blood samples were collected from 16 crossbred, pregnant, lactating cows at the intervals of each two weeks. From these collected samples, serum hormone concentration was determined by Radioimmunoassay $\left({ }^{125}\right.$ I-RIA) technique and IgG concentration was assayed by using the method involves antigen diffusing radially. Results of present study revealed that concentration of E2$17 \beta$ is insignificant from $1^{\text {st }}$ to the $4^{\text {th }}$ month of gestation and tended to increase from the 4.5 th month to the end of gestation. After parturition E2-17 $\beta$ returned to its normal level on $30^{\text {th }}$ day of postpartum. Further, concentration of testosterone hormone start increasing $(29.76 \mathrm{pg} / \mathrm{ml})$ from the $4^{\text {th }}$ month, after this it gradually increased $(\mathrm{P}<0.01)$ with the advances of gestation $(185.40 \mathrm{pg} / \mathrm{ml})$ up to the $9^{\text {th }}$ month, thereafter testosterone level reached to the peak $(197.80 \mathrm{pg} / \mathrm{ml})$ at the end of pregnancy as compared to the average during non-pregnancy period. Concentration of $\operatorname{IgG}$ remained at basal level from the $1^{\text {st }}$ to $6.5^{\text {th }}$ month of gestation that averaged $23.65 \mathrm{~g} / \mathrm{l}$. Thereafter a sharpest increase in $\mathrm{IgG}$ level was occurred up to the 8.5 th month that followed by a depression in the subsequent period until parturition. It can be concluded that concentrations of E2-17 $\beta$ and testosterone remained at low levels around the $4^{\text {th }}-5^{\text {th }}$ month and progressively increased and showing a sharp rise in the 9.3 month of gestation. Moreover, the levels of IgG insignificantly changed until the $6.5^{\text {th }}$ month of pregnancy and a sharpest rise occurred in the $8.5^{\text {th }}$ month of gestation.
\end{abstract}

* Corresponding author

E-mail: drsalahgabr@yahoo.com (Salah Gabr)

Peer review under responsibility of Journal of Experimental Biology and Agricultural Sciences.

Production and Hosting by Horizon Publisher India [HPI] (http://www.horizonpublisherindia.in/).

All rights reserved.
All the articles published by Journal of Experimental Biology and Agricultural Sciences are licensed under a Creative Commons Attribution-NonCommercial 4.0 International License Based on a work at www.jebas.org.

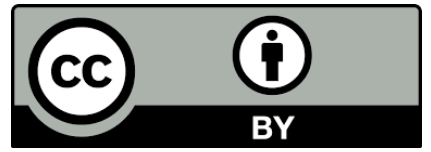




\section{Introduction}

Changes in hormones concentration and functioning during pregnancy period of ruminants have been widely studied by various researchers (Al-Anbaky, 2009; Harichadan et al., 2014). Among these, estrogen is essential hormones which help in maintain pregnancy and initiation of parturition. Further, Estradiol-17 $\beta$ stimulates the synthesis of endometrial oxytocin receptors and reduce the rate of $\mathrm{LH}$ releases which is must for the maintain progesterone production during early pregnancy (Peters \& Ball, 1995).

The important roles of $\mathrm{E}_{2}-17 \beta$ and testosterone hormone during pregnancy period may be attributed to that the biochemical reactions for the formation of these hormones are the same, and the male sex hormone testosterone can serve as precursor for the synthesis of $E_{2}-17 \beta$ and their pathway involving the conversion of testosterone to $E_{2}-17 \beta$ is more significant in the ovary (Tietz, 1982). Moreover, during pregnancy period, feto-placental tissues appears to be the major site of estrogens biosynthesis was able to convert testosterone to $E_{2}-17 \beta$ in the basal membrane of theca cells (Tietz, 1982; Solomon, 1994; Peters \& Ball, 1995). Estrogen plays an essential role in the maintenance of pregnancy and initiation of parturition (Peters \& Ball, 1995). On the other side, testosterone hormone may modify placental function and had an effect on transport of nutrients to the fetus (Carlsen et al., 2006).

Concerning the IgG levels, Janeway et al. (2002) reported that $\mathrm{IgG}$ is the main immunoglobulin in the blood system accounting for approximately $80 \%$ of the total circulating immunoglobulin, whereas its function is to bind pathogenic agents and induce an immune response.

According to Harichandan et al. (2014), the relationship between testosterone hormone and each of $\mathrm{E} 2-17 \beta$ and $\mathrm{IgG}$ may induce the high production of steroid hormones throughout pregnancy course, but a wide discrepancy and changes in these items have been reported by Min et al. (2002), Carlsen et al. (2006) and AlAnbaky (2009). The present study was therefore undertaken to determine the changes in the general profile of E2-17ß, testosterone and $\operatorname{IgG}$ concentrations throughout pregnancy as compared with non-pregnancy period of cows.

\section{Materials and Methods}

A total of 16 crossbred (Brown Swiss 50\% and Balady 50\%) pregnant and lactating cows, approximating 4-5 years of age and weighing $340 \pm 20 \mathrm{~kg}$ were used for current study and changes in $\mathrm{E} 2-17 \beta$, testosterone as well as $\mathrm{IgG}$ levels during pregnancy period were studied in detail.
The animals were in moderate milking ability during postpartum period and observed daily for estrus and considered to be in estrus when they stood to be mounted by another cows. Then, jugular blood samples were collected from these non-pregnant cows and were considered as samples for control period. Natural mating with pure Brown Swiss bull was carried out for all cows. Records of breeding dates were maintained. Blood samples were collected from all mated cows from the 1st days of mating and continued throughout pregnancy at the intervals of two weeks. Trans rectal palpation of the reproductive tract on day 60 of post mating was used as a pregnancy test. The animals were fed on concentrated diets $(17 \%$ crude protein, $2.5 \%$ ether extract and $16.5 \%$ crude fiber) according to their trimester of pregnancy. The animals had free access to graze green forage throughout pregnancy period. Trace elements mixtures (Pfizer Co.) were added daily for all animals by $1.5 \mathrm{~g} / \mathrm{kg}$ dry matter. Drinking water and rice straw were offered freely ad lib.

The concentrations of E2-17 $\beta$ and testosterone hormones were determined by radioimmunoassay technique (Elbanna et al., 1988 ) using solid phase coated tubes kits purchased from diagnostic systems laboratories Inc., Webstir, Texas, USA. Serum IgG concentration was measured using kit for IgG of the Binding Sit Limited Co., Birmingham, UK.

Statistical analysis of the obtained data were carried out, whereas the differences between mean values of the items of nonpregnancy period (control period) and each of mean values of pregnancy period of cows were tested by paired " $t$ " test according to Snedecor \& Cochran (1994).

\section{Results and Discussion}

Data presented in Tables 1 and Figure 1 showed that E2-17 $\beta$ concentrations varied from $32.31 \mathrm{pg} / \mathrm{ml}$ (during non-pregnancy period) to $37.12 \mathrm{pg} / \mathrm{ml}$ (in the 4 th month of gestation) and the difference between these two means was found insignificant. Thereafter, the concentration of $\mathrm{E} 2-17 \beta$ increased $(\mathrm{P}<0.01)$ to 38.67 and $42.64 \mathrm{pg} / \mathrm{ml}$ in the $4.5^{\text {th }}$ and $5^{\text {th }}$ month of gestation,

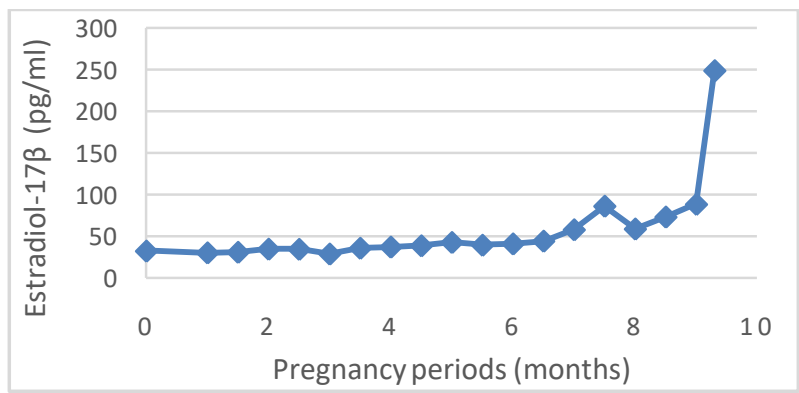

Figure 1 Concentration of Estradiol-17 $\beta$ (pg/ml) in non-pregnant and during pregnancy periods (months) in Cows 
Table 1 Changes in estradiol-17 $\beta$, testosterone and $\mathrm{I}_{\mathrm{g}} \mathrm{G}$ levels during the pregnancy period of cows

\begin{tabular}{|c|c|c|c|}
\hline \multirow{2}{*}{$\begin{array}{l}\text { Pregnancy Period } \\
\text { (Months) }\end{array}$} & \multicolumn{3}{|c|}{ Hormonal Concentration (pg/ml) } \\
\hline & Estradiol-17 $\beta$ & Testosterone & $\mathrm{I}_{\mathrm{g}} \mathrm{G}(\mathrm{g} / \mathrm{L})$ \\
\hline Non-pregnant & $32.31 \pm 1.68$ & $24.58 \pm 1.45$ & $25.41 \pm 1.52$ \\
\hline 1.0 & $30.18 \pm 1.32$ & $22.72 \pm 1.12$ & $23.76 \pm 1.67$ \\
\hline 1.5 & $30.85 \pm 0.97$ & $23.41 \pm 2.04$ & $25.20 \pm 0.97$ \\
\hline 2.0 & $34.60 \pm 1.02$ & $21.85^{*} \pm 2.33$ & $23.59 \pm 1.05$ \\
\hline 2.5 & $34.40 \pm 1.11$ & $23.31 \pm 0.73$ & $25.56 \pm 1.36$ \\
\hline 3.0 & $28.78 \pm 0.89$ & $22.87 \pm 0.79$ & $29.01 \pm 1.09$ \\
\hline 3.5 & $35.71 \pm 1.19$ & $23.92 \pm 1.03$ & $27.55 \pm 1.39$ \\
\hline 4.0 & $37.12 \pm 1.73$ & $29.76^{*} \pm 1.35$ & $26.10 \pm 1.87$ \\
\hline 4.5 & $38.69 * \pm 1.39$ & $42.25^{* * \pm 1.97}$ & $26.28 \pm 1.05$ \\
\hline 5.0 & $42.67 * \pm 2.01$ & $77.32 * * \pm 2.99$ & $30.43 \pm 1.12$ \\
\hline 5.5 & $39.34 * \pm 2.01$ & $73.82 * * \pm 3.63$ & $31.53 \pm 2.01$ \\
\hline 6.0 & $40.95^{* *} \pm 3.50$ & $88.8 * * \pm 4.05$ & $28.01 \pm 1.76$ \\
\hline 6.5 & $44.25^{* *} \pm 2.87$ & $111.5 * * \pm 5.79$ & $23.65 \pm 1.34$ \\
\hline 7.0 & $57.9^{* * \pm 2.69}$ & $167.73 * * \pm 6.3$ & $32.61 * \pm 2.02$ \\
\hline 7.5 & $86.2^{* *} \pm 2.57$ & $154.2 * * \pm 3.26$ & $38.36^{*} \pm 1.39$ \\
\hline 8.0 & $58.8^{* * \pm 3.11}$ & $162.6 * * \pm 4.21$ & $43.77 * * \pm 0.88$ \\
\hline 8.5 & $73.2^{* * \pm 3.72}$ & $158.9 * * \pm 3.88$ & $57.79 * * \pm 1.09$ \\
\hline 9.0 & $88.4^{* * \pm 4.18}$ & $185.4 * * \pm 4.95$ & $46.80^{* * \pm \pm 1.13}$ \\
\hline 9.3 & $248.86^{* * \pm 10.75}$ & $197.8 * * \pm 3.84$ & $34.59 * \pm 1.45$ \\
\hline
\end{tabular}

*Significant difference at $\mathrm{P}<0.05 \quad * *$ Significant difference at $\mathrm{P}<0.001$

respectively. In the $5.5^{\text {th }}$ month of pregnancy E2-17 $\beta$ concentrations increased $(\mathrm{P}<0.01)$ progressively with the advance of gestation and reach maximum $(248.86 \mathrm{pg} / \mathrm{ml})$ at the end of pregnancy course.

Findings of present study are associated with the data of previous studies, whereas the concentrations of estrone and E2-17 $\beta$ in bovine blood plasma remain low during the early period of gestation and gradually increased throughout mid, to late gestation (Hung \& Prakash, 1990; Patel, 1999). Similarly, El-Fouly et al. (1998a) showed that E2-17 $\beta$ levels in crossbred cows did not change in the $1^{\text {st }}$ trimester while it significantly increased in the $2^{\text {nd }}$ trimester and increased sharply at the end of the $3^{\text {rd }}$ trimester of gestation, reached to its peak on day 1 before calving. Mekonnin et al. (2017) conducted a study for estradiol level detection in pregnant heifers and cows. In both cows and heifers, higher estradiol concentrations were recorded during the first trimester of pregnancy as compare to other stages of pregnancy. Similarly, Opara et al. (2006) reported higher level of estradiol in pregnant heifers as compared to estrus or other reproductive conditions (anestrus or diestrus) and in this situation findings of present study are in agreement with these earlier reports.

Hirako et al. (2003) reported that during the $1^{\text {st }}$ trimester of gestating cows, E2-17 $\beta$ remained at basal levels until day 80 , followed by an increase in estrone and E217 $\beta$ after day 80 of gestation. Also, Al-Anbaky (2009) suggested that in pregnant cow's plasma E2 $-17 \beta$ levels varied from $9 \mathrm{pg} / \mathrm{ml}$ (in the first third of pregnancy) to $282.60 \mathrm{pg} / \mathrm{ml}$ (during the last month of gestation).Similar findings were reported by El-Masry et al. (1997) in a study conducted on Egyptian buffaloes. Several potential mechanisms affect the level of E2-17 $\beta$ during the pregnancy period, whereas the concentration of fetal cortisol from fetal adrenals helps in E2-17 $\beta$ releases from placenta (Gitau et al., 2005). Further, the conversion of testosterone hormone into E2$17 \beta$ held at the granulosa cells by the action of aromatase (Peters \& Ball, 1995; Hirako et al. 2003). Also, sex of fetus and the levels of progesterone hormone might also associate with the releases 
and concentration of E2-17 (EL-Fouly et al., $1998 \mathrm{~b}$ ). The higher levels of E2-17 $\beta$ during third trimester of pregnancy have evoked normal development of mammary alveolar tissues which might be involved in the primary myometrium and triggering the prostaglandin release in farm animals; this would help in further myometrium contractions (Peters \& Ball, 1995). A combination of all these mechanisms is also conceivable.

Functions of testosterone hormone throughout pregnancy period have been well reported previously, this hormone induce the production of plasma progesterone binding proteins during pregnancy which help in maintaining high progesterone levels (Wyk et al., 1994).

Maternal testosterone may also cross the placenta and exert a direct effect on fetal growth and / or energy homeostasis (Carlsen et al., 2006) as well as testosterone with estrogen accelerates blood flow to the uterus during parturition (Min et al., 2002). In results of present study, testosterone concentration remained at basal levels $(23.92 \mathrm{pg} / \mathrm{ml})$ until the $3.5^{\text {th }}$ month of gestation, thereafter testosterone level began to increase $(\mathrm{P}<0.01)$ progressively with the advance of gestation and a sharpest rise recorded $197.80 \mathrm{pg} / \mathrm{ml}$ in the $9.3^{\text {th }}$ months of gestation (Tables 1 and Figure 2). These results are associated with finding of by Gaiani et al. (1984) who found that plasma testosterone levels in cows ranged between 20 to $50 \mathrm{pg} / \mathrm{ml}$ until about 90 days of pregnancy, then it increase progressively to about $220 \mathrm{pg} / \mathrm{ml}$ around 270 days of gestation. Moreover, Al-Anbaky (2009) revealed that testosterone levels in cows were $0.32 \mathrm{ng} / \mathrm{ml}$ in the $3 \mathrm{rd}$ month of gestation, increase to $0.541 \mathrm{ng} / \mathrm{ml}$ at the end of $8^{\text {th }}$ month of gestation. Similarly, Emara (2015) reported that nonpregnant cows have low level of testosterone $(0.08 \mathrm{ng} / \mathrm{ml})$ and showed a continuous gradual increase throughout pregnancy period till day 3-7 of prepartum $(0.28 \mathrm{mg} / \mathrm{ml})$, followed by a drop on $30^{\text {th }}$ day of postpartum which averaged 0.097 and $0.06 \mathrm{ng} / \mathrm{ml}$, respectively. Similar findings were reported by Peters \&Ball

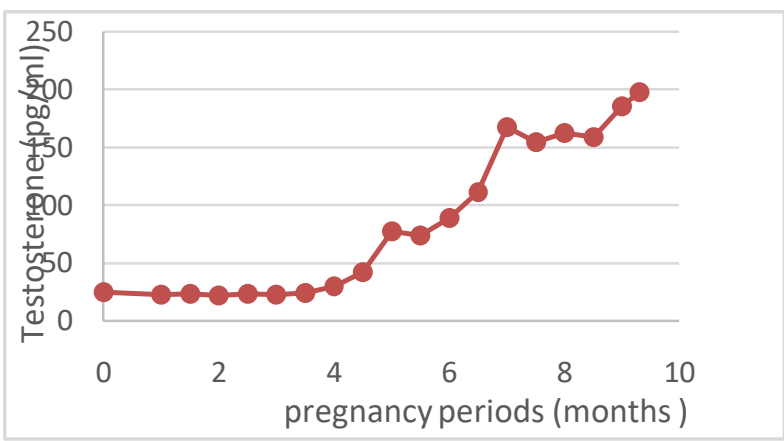

Figure 2 Concentration of Testosterone (pg/ml) in non-pregnant and during pregnancy periods (months) in cows.

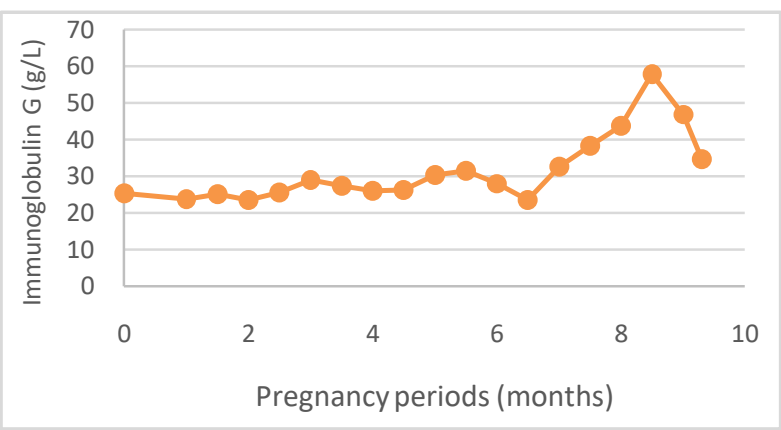

Figure 3 Concentration of Immunoglobulin G $(\mathrm{g} / \mathrm{L})$ in non-pregnant and during pregnancy periods (months) in cows

(1995) and Al-Anbaky (2009). According to these researchers this gradually augmentation in the level of testosterone at advance stage of gestation may be attributed to the biosynthesis and excretion of testosterone hormone by several sources such as placental tissues, ovary, mammary gland and fetal males.

As shown in tables 1 and figure 3, serum $\operatorname{IgG}$ levels showed insignificant fluctuation from the $1^{\text {st }}$ month of the $6.5^{\text {th }}$ months of gestation. Thereafter, IgG increased sharply in the subsequent months and it reached to the peak in the $8.5^{\text {th }}$ months, followed by the depression in IgG levels in the $9^{\text {th }}$ and $9.3^{\text {th }}$ months of gestation. General trend of $\operatorname{IgG}$ levels throughout pregnancy period are in agreement with the findings of Carolina et al. (2014) in domestic animals and by Malek et al. (1996) in woman; these researchers reported that fetal IgG begins to increase from 13 to 18 weeks of gestation and this improvement continuously increases till the end of final trimester and typically exceed the maternal $\operatorname{IgG}$ concentrations. This increases in globulin level with the advance of gestation might be due to change in their endocrine profile, since an animal's transition occurs from non-gravid to gravid state and their transformation might have influenced more production of globulin by Blymphocytes (Harichandan et al., 2014).

In addition, high circulating levels of estrogen during pregnancy course (El-Fouly et al., 1998 a; Patel, 1999; Hirako et al., 2003) and glucocorticoids near the onset of parturition can suppress important lymphocyte function (Levkut et al., 2002). Concerning the depression in $\operatorname{IgG}$ at postpartum period; Herr et al. (2011) revealed that plasma $\operatorname{IgG}$ level recovered by the $4^{\text {th }}$ week of postpartum and the extent of $\mathrm{IgG}$ reduction seemed to be depended on the initial $\mathrm{IgG}$ concentration. Such reduction in immunoglobulin concentration at the terminal stage of pregnancy in cows might have occurred because the transition of globulin fraction from the blood to the mammary gland and tubular genital tract (Liberg,1977; Harichandan et al., 2014). 
From the results of present study it can be concluded that interaction and changes in the levels of E2-17 $\beta$ and testosterone hormones were augmented and coincided with the advance of gestation for sustenance of pregnancy, showing higher concentrations during the late months of pregnancy compared to non-pregnancy ones, and the levels of IgG insignificantly changed until the $6.5^{\text {th }}$ months of pregnancy and a sharpest rise occurred in the $8.5^{\text {th }}$ months of gestation.

\section{Conflict of Interest}

The authors declare that there is no conflict of interest in this manuscript.

\section{References}

Al- Anbaky KIH (2009) A study of serum steroid hormones concentration of pregnant cows. Iraqi Journal of Veterinary Medicine 33: $180-182$.

Carolina L, Rodrigues MN, Favaron PO, Miglino MA (2014) Immunoglobulin transport during gestation in domestic animals and humans: A review. Open Journal of Animal Sciences 4:323-336.

Carlsen SM, Jacobsen G, Romundstad P (2006) Maternal testosterone levels during pregnancy are associated with offspring size at birth. European Journal of Endocrinology.155:365-370.

Elbanna IM, El-Asrag HA, Gamal MH (1988) An improved method for estradiol-17 $\beta$ radioimmunoassay. Isotope and Radiation Researches 20: 141-144.

El-Fouly HA, El- Masry KA, Gamal MH (1998a) Maternal body weight during trimester of pregnancy as an indicator of the development of male and female fetuses and their relationship with some steroid hormones and blood biochemical levels in Baladi cows. Zagazig Veterinary Journal 26: 56-68.

El-Fouly HA, El-Masry KA, Gamal MH (1998b) Effect of calves sex on some reproduction traits of Balady cows and growth performance of their Balady and crossbred calves. Zagazig Veterinary Journal 26: 69-78.

El-Masry KA, Yousef HM, Farghaly HA (1997) Hormonal pattern in pregnant Egyptian buffuloes in relation to their productivity. Buffalo Journal 2:147-156.

Emara SS (2015) Oxidative stress in relation to physiological and productivity changes in cattle. Ph.D. Thesis submitted to the Faculty of Agriculture, Ain Shams University.

Gitau R, Adams D, Fisk N, Glover V (2005) Fetal plasma testosterone correlated positively with cortisol. Archives of Disease in Childhood, Fetal and Neonatal Edition 90: 166-169.
Harichandan PP, Mohanty DN, Das S, Patra BK (2014)Hormonal and immunological studies in different trimester of pregnancy in cows. Indian Journal of Animal Reproduction 35: 42-44.

Herr M, Bosdedt H, Failing K (2011) Ig G and Ig M levels in dairy cows during the periparturient period. Theriogenology 15 : 377-385.

Hirako M, Takahashi T, Takahashi H, Patel O, Domeki I (2003) Changes in plasma estrogen concentrations during the first trimester of gestation in dairy cows: comparison with the origin of embryos and featal number. Japan Agricultural Research Quarterly 37: 195-200.

Hung NN, Prakash BS (1990) Influence of gestation on blood plasma concentration of oestrone and oestrone sulphate in karan swiss cows and Murrah buffuloes. Brazilian Veterinary Journal 146: 449-456.

Janeway CA, Travers P, Walport M, Shlomchik M (2002) Immunobiologia: O sistemaimunenasaude e nadoenca. Artmed, Porto Alegre.

Levkut M, Pistl J, Revajova V, Choma J, Levkutova M, David $\mathrm{V}$ (2002) Comparison of immune parameters in cows with normal and prolonged involution time of uterus. Veterinarni Medicina UZPI (Czech Republic) 47 : 277-282.

Liberg P (1977) Agarose gel electrophoretic fractionation of serum proteins in adult cattle. A study of clinically healthy cows. Acta Veterinaria Scandinavica 18:40-53.

Malek A, Sager R, Kuhn P, Nicolaides KH, Schneider H (1996) Evolution of Maternofetal transport of immunoglobulins during human pregnancy. American Journal of Reproductive immunology, 36:248-255.

Mekonnin AB, Howie AF, Riley SC, Gidey G, Tegegne DT, Desta G, Ashebir G, Gebrekidan B, Harlow CR (2017) Serum, milk, saliva and urine progesterone and estradiol profiles in crossbred (Zebu x Holstein Friesian) dairy cattle. Animal Husbandry, Dairy and Veterinary Science 1: 1-10. DOI: 10.15761/AHDVS.1000118

Min KR, Munarriz N, Kim N, Goldstein I, Traish A (2002) Effects of ovariectomy and vaginal lubrication in the animal model. American Journal of obstetrics and Gynecology 187:13701376.

Opara MN, Okoli1 CI, Udo H, Adeyemo O (2006) Ovarian morphology and estradiol-17ß concentrations in serum and follicular fluid of slaughtered zebu cattle in Ibadan, Nigeria. Veterinarski Arhiv 76: 403-411. 
Patel OV (1999) Plasma oestrone and oestradiol concentrations throughout gestation in cattle: relationship to stage of gestation and fetal number. Research in Veterinary Science 66:129-133.

Peters AR, Ball PJH (1995) parturition and lactation. In: Reproduction in Cattle, $2^{\text {nd }}$ edn, Blackwell Science Ltd, UK, Pp. 127-144.

Gaiani R, Chiesa F, Mattioli M, Nannetti G, Galeati G (1984) Androstenedione and testosterone concentrations in plasma and milk of cow throughout pregnancy. Journal of Reproduction and Fertility 70: 55-59.

Snedecor GW, Cochran WG (1994) Statistical Methods. $8^{\text {th }}$ Ed.,
The Iowa state University press, Ames, USA.

Solomon S (1994) The primate placenta as an endocrine organ: steroids. In: Knobil E, Neill JD (Eds.), The physiology of reproduction, Raven Press, New York, USA, Pp. 863-873.

Tietz NW (1982) Fundamental of clinical chemistry. In: Norbert WT (Ed.), Sounders Company, Philadelphia.

Wyk VN., Van Ande RJ, Lauw AI (1994) Concentrations of plasma total and unbound progesterone and testosterone during pregnancy in Cape Porcupines. Comparative Biochemistry and Physiology 108A:265-271. 